\title{
Improving Yield and Quality of Some Olive Cultivars Using an Integrated and Balanced Fertilization Program Grown in Calcareous Soil
}

\author{
A.I. Rezk; ${ }^{1}$ O.A . Nofal $^{2}$ and A. B. El-Nasharty ${ }^{1}$
}

\begin{abstract}
Four olive cultivars 10-years old with different production purposes (oil, table-and double purposes) which grown in calcareous soils under drip irrigation system at North West region of Egypt were evaluated for their responses to an Integrated and Balanced Fertilization program (IBF) comparing with normal farm fertilization (NFF) during two successive seasons (2006, 2007). Results showed that remarkable and significant differences between cultivars in leaf-macro and micronutrients contents, olive yield and both oil and total acidity percentage as a result of using (IBF). Correlation coefficients cleared that there are high positive relations between leaf nutrients contents and olive yield. They reached to highest values with potassium $(r=0.63)$ and both nitrogen and copper $(r=0.58)$. With respect to oil percent, positive relations were also observed with potassium $(r=0.38)$,copper $(r=0.26)$, calcium $(r=0.24)$ and phosphorus $(r=0.18)$. Otherwise, negative relations were found with total acidity, particularly potassium ( $r=-0.72)$ and copper $(r=-0.55)$ and to a less extent, with phosphorus $(r=-0.51)$,calcium $(r=-0.49)$, magnesium $(r=-0.48)$, nitrogen $(r=-0.38)$ and iron $(r=-0.33)$.It is clear that potassium and copper had the most effective role on olive yield and its quality. There were also found positive relation between olive yield and its oil content $(r=0.20)$ and in contrast, negative relations between each of them and total acidity ( $r=-0.48$ and-0.14), respectively.
\end{abstract}

The olive yield of the four cultivars and their oil contents were increased as a result of using (IBF) program where the increasing rates ranged from $23-30 \%$ and from $13-26 \%$, respectively. But the total acidity was decreased by rates ranged from $12-33 \%$. In accordance, the highest olive yield was $28.9 \mathrm{~kg} /$ tree with $20.7 \%$ of oil and $0.7 \%$ of total acidity for the double-purpose cultivar (Picual) and the lowest one was $20.6 \mathrm{~kg} /$ tree with $7.7 \%$ of oil and $0.8 \%$ of total acidity for the table-purpose cultivar (Egazy, local cultivar).

It can be concluded that, the addition of macronutrients as soil application through the drip irrigation system and micronutrients as foliar application in an integrated and balanced fertilization (IBF) program to the four studied cultivars, has effective role for improving olive yield and its quality.

\section{INTRODUCTION}

The worldwide increase consumption from table olives and olive oil during recent years stimulated olive growers and oil producers to improve and increase the production .Applying nutrients less than crop requirements reduce olive yield, while applying excess amounts may causes reducing in fruit quality, increasing environmental pollution (Shaaban et al., 2004), and therefore, the importance of integrated balanced fertilization (IBF).To evaluate the trees nutritional status, most of the previous studies concentrated on determining the leaf nutrient content at the middle of growth season (Reuter and Robenson, 1986 and Hanson, 1996).On the other hand, amendment of the deficient nutrients in an advanced growth stage would not enable the plants to give the target yield.

Experiments carried out in olive orchards indicated that the trees are suffering from nutrient deficiencies (Fernandez - Escobar, 1998 and Viesman et al., 2002). Moreover, many researches point out that olive trees varied among plant species and cultivars in their nutrient status especially in the absorption and translocation (Procpio and Wallas, 1979, Zaharieva, 1982, Mobark et $a l ., 1992)$ and their yields and fruit quality (Rezk et al., 2005).

The present work was designed to characterize the response of using an integrated and balanced fertilization program on yield and quality of some olive cultivars under drip irrigation system.

\section{MATERIALS AND METHODS}

The trial was conducted during 2006 and 2007 seasons on four olive cultivars( 10 years old), namely Picual , Manzanello, Coratina and Egazy.

They were grafted on Balady rootstock and grown in sandy loam soil in olive private farm at Wadi El-Natron region, Egypt. The soil of the experimental site is loamy sand with $6.9 \%$ calcium carbonate, $0.33 \%$ organic matter, an electrical conductivity of $0.52 \mathrm{dS} / \mathrm{m}$ and a $\mathrm{pH}$ of 8.2. Two Fertilizer programs were applied which are the control (Normal Farm Fertilization; NFF): $300 \mathrm{~g} \mathrm{~N}$ as ammonium nitrate, $100 \mathrm{~g} \mathrm{P}_{2} \mathrm{O}_{5}$ as phosphoric acid, $400 \mathrm{~g}$ $\mathrm{K}_{2} \mathrm{O}$ as potassium sulfate, $0.0 \mathrm{~g} \mathrm{MgO}$ as magnesium sulfate/tree/year and the integrated and balanced fertilization program(IBF): $400,500 \mathrm{~g} \mathrm{~N}, 200,250 \mathrm{~g}$ $\mathrm{P}_{2} \mathrm{O}_{5}, 500,750 \mathrm{~g} \mathrm{~K}_{2} \mathrm{O}, 25,50 \mathrm{~g} \mathrm{MgO}, 1.0 \mathrm{~g} \mathrm{Fe}, 1.0 \mathrm{~g} \mathrm{Mn}$, $1.0 \mathrm{~g} \mathrm{Zn}, 0.20 \mathrm{~g} \mathrm{Cu}$ and $0.10 \mathrm{~g} \mathrm{~B} /$ tree year for 2006 and

\footnotetext{
${ }^{1}$ Fertilization Technology Department.

2 Plant Nutrition department, National Research Centre, Cairo, Egypt. Received November 10, 2008, Accepted December 14, 2008
} 
2007 seasons, respectively. All macronutrients, were added through drip irrigation and micronutrients in EDTA chelated form except B as Sodium borate form (borax)were foliar sprayed three times during the growth season, i.e. before flowering, after fruit set and one month later.

The experimental design was factorial in randomized complete block design with 4 replicates each one was represented by 16 trees for each cultivar.

Leaf sampling was performed in mid of growing season for determination of nutrient contents as outline in Chapman and Pratt (1978). The harvest olive yield and both oil and total acidity percentages were determined for each cultivar.

The obtained data were subjected to statistical analysis for least significant difference (LSD) using PCSAS software (SAS Institute, 1988).

\section{RESULTS}

It is clear that leaf mineral content of the four olive cultivars was significantly different due to modification the fertilizer program over the two seasons (Tables 1,2). It is clear that for the control (NFF), the concentrations of all nutrients were less than that in treated trees (IBF). Results indicated that Picual cultivar posed the highest leaf $\mathrm{N}$-content $(1.61 \%)$ which increased by $28.8 \%$ as compared with control. The results of leaf P-content for all cultivars did not show any significant differences by applying IBF program except for Egazy cultivar in which P-content was increased from 0.06 to $0.10 \%$. With respect to leaf K-content, the data in Table (2) indicate that there are a significant differences either between cultivars or treatments. In addition ,the maximum concentration of potassium was found with Manzanello cultivar, whereas its leaf content was $2.15 \%$ in IBF treatment with an increasing percent of $30 \%$ compared to the control .A similar trend was observed for leaf $\mathrm{Ca}$ content,but in Coratina cultivar the leaf content was twice that of control. In addition, all olive cultivars were highly responded to IBF program which reflected to an increase in leaf $\mathrm{Mg}$-content which reached more than the control by $59 \%$.

Leaf- micronutrients content of all olive cultivars was improved in sequences to applying IBF treatment (Table2). The table-purpose (Egazy)cultivar was superior with leaf Fe-content while the double-purpose (Manzanello) gave the heighest $\mathrm{Mn}, \mathrm{Zn}$ and $\mathrm{Cu}$ contents.

As shown in Table (3), the average olive yield of the two seasons was varied between cultivars in the following order: picual > Manzanello > Coratina > Egazy. On the other hand, applying IBF program significantly affected the olive yield of all cultivars with different degrees and increasing percent in the yield ranged from 23\% for Manzanello to 30\% for Egazy comparing to the control.

Table 1. Leaf macronutrient contents of olive cultivars as affected by farm and integrated balanced fertilizations (average of two seasons 2006 and 2007)

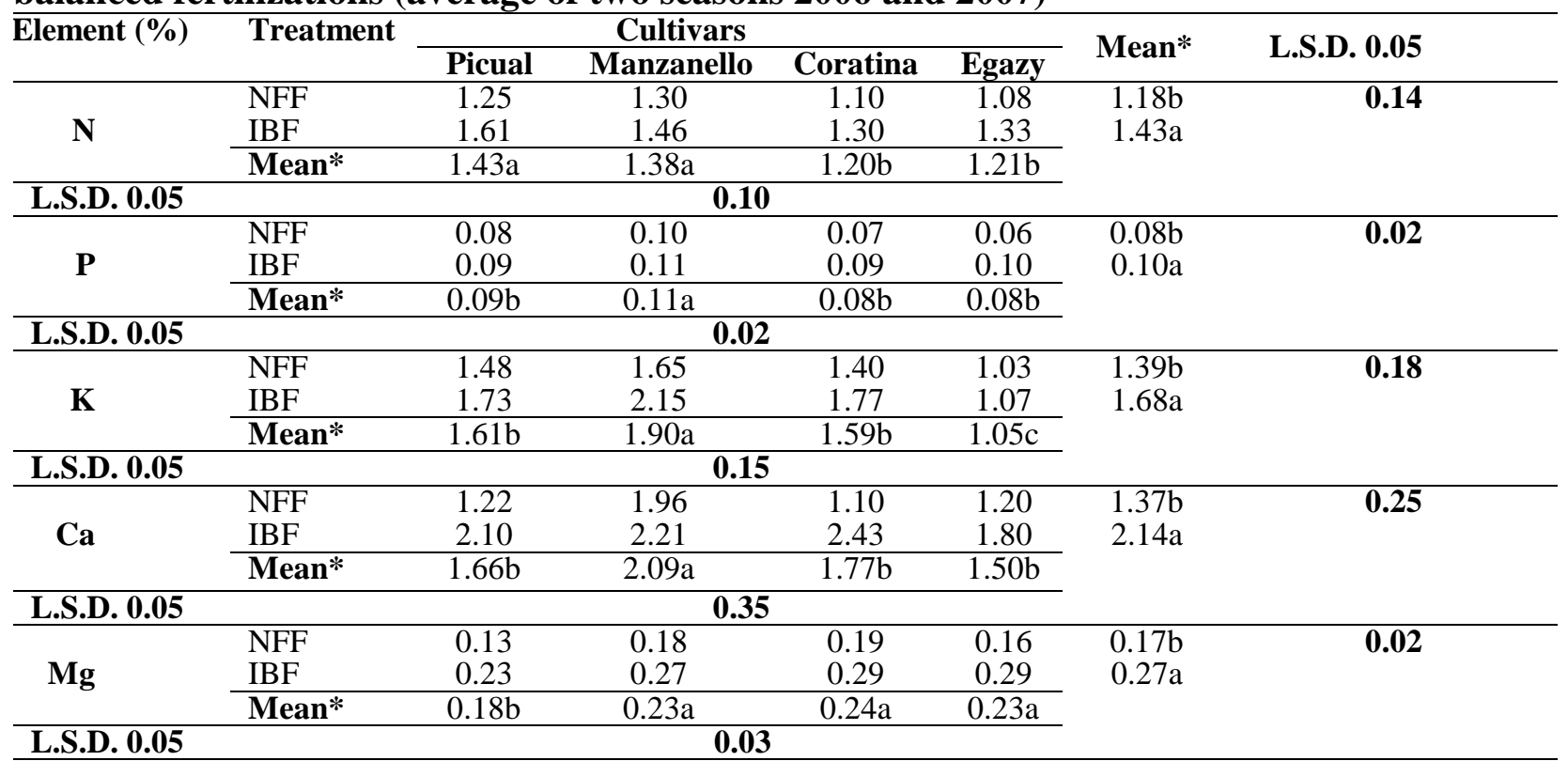

* Mean followed by the same letter (s) are not significantly different at 0.05 level .

NFF $=$ Normal Farm Fertilization

$\mathrm{IBF}=$ Integrated Balanced Fertilization 
Table 2. Leaf micronutrients contents of olive cultivars of as affected by farm and integrated balanced fertilizations (average of two seasons 2006 and 2007)

\begin{tabular}{|c|c|c|c|c|c|c|c|}
\hline \multirow{2}{*}{$\begin{array}{c}\text { Element } \\
(\mathbf{p p m})\end{array}$} & \multirow[t]{2}{*}{ Treatment } & \multicolumn{4}{|c|}{ Cultivars } & \multirow{2}{*}{ Mean* } & \multirow{2}{*}{$\begin{array}{c}\text { L.S.D. } \\
\text { 0.05 }\end{array}$} \\
\hline & & Picual & Manzanello & Coratina & Egazy & & \\
\hline \multirow{3}{*}{$\mathbf{F e}$} & NFF & 87 & 145 & 95 & 71 & $99.5 b$ & \multirow{3}{*}{19.0} \\
\hline & IBF & 133 & 163 & 135 & 166 & $149.3 \mathrm{a}$ & \\
\hline & Mean* & $110.0 \mathrm{~b}$ & $154.0 \mathrm{a}$ & $115.0 \mathrm{~b}$ & $118.5 b$ & & \\
\hline \multicolumn{2}{|c|}{ L.S.D. 0.05 } & \multicolumn{4}{|c|}{26.0} & & \\
\hline \multirow{3}{*}{ Mn } & NFF & 24 & 38 & 28 & 21 & $27.75 b$ & \multirow{4}{*}{4.2} \\
\hline & IBF & 29 & 43 & 39 & 42 & $38.25 \mathrm{a}$ & \\
\hline & Mean* & $26.5 \mathrm{c}$ & $40.5 \mathrm{a}$ & $33.5 \mathrm{~b}$ & $31.5 \mathrm{bc}$ & & \\
\hline \multirow{4}{*}{ Zn } & 0.05 & & & & & & \\
\hline & NFF & 19 & 30 & 14 & 18 & \multirow{4}{*}{$\begin{array}{l}20.25 \mathrm{~b} \\
28.50 \mathrm{a}\end{array}$} & \multirow{4}{*}{3.4} \\
\hline & IBF & 26 & 36 & 26 & 26 & & \\
\hline & Mean* & $22.5 \mathrm{~b}$ & $33.0 \mathrm{a}$ & $20.0 \mathrm{~b}$ & $22.0 \mathrm{~b}$ & & \\
\hline L.S. & 0.05 & & & & & & \\
\hline \multirow{3}{*}{$\mathbf{C u}$} & NFF & 5.1 & 5.7 & 4.2 & 2.6 & \multirow{4}{*}{$\begin{array}{l}4.40 \mathrm{~b} \\
6.53 \mathrm{a}\end{array}$} & \multirow{4}{*}{1.1} \\
\hline & IBF & 6.5 & 9.0 & 5.7 & 4.9 & & \\
\hline & Mean* & $5.80 \mathrm{ab}$ & $7.35 \mathrm{a}$ & $4.95 \mathrm{~b}$ & $3.75 b$ & & \\
\hline L.S & 0.05 & & & & & & \\
\hline
\end{tabular}

* Mean followed by the same letter (s) are not significantly different at 0.05 level .

NFF $=$ Normal Farm Fertilization

$\mathrm{IBF}=$ Integrated Balanced Fertilization

Concerning oil percentage, results in Table(3) showed that this character was significantly affected by olive cultivar. In this respect, oil percentage of Picual under the IBF program was generally the highest (20.7\%) whereas for Egazy was the lowest (7.7\%). The variations in total acidity percentages between the four tested cultivars were also significant. Otherwise, the IBF treatment significantly decreased total acidity by 20 $33 \%$ comparing with the control.

Table 3. Yield, oil and total acidity of olive cultivars as affected by farm and integrated balanced fertilizations (average of two seasons 2006 and 2007)

\begin{tabular}{|c|c|c|c|c|c|c|c|}
\hline Cultivars & $\begin{array}{l}\text { Character } \\
\text { Treatment }\end{array}$ & $\begin{array}{c}\text { Olive } \\
\text { yield } \\
\text { (Kg / tree) }\end{array}$ & $\begin{array}{c}(\%) \\
\text { Increasing }\end{array}$ & Oil (\%) & $\begin{array}{c}(\%) \\
\text { Increasing }\end{array}$ & $\begin{array}{c}\text { Total acidity } \\
(\%)\end{array}$ & $\begin{array}{c}(\%) \\
\text { Decreasing }\end{array}$ \\
\hline Picual & $\begin{array}{c}N F F \\
\text { IBF }\end{array}$ & $\begin{array}{l}23.0 \\
28.9\end{array}$ & $-\overline{26}$ & $\begin{array}{l}17.6 \\
20.7\end{array}$ & $\begin{array}{c}- \\
18\end{array}$ & $\begin{array}{l}1.2 \\
0.8\end{array}$ & $-\overline{3}$ \\
\hline \multicolumn{2}{|c|}{ Mean" } & 25.95a & - & 19.15a & - & $1.00 \mathrm{a}$ & - \\
\hline Manzanello & $\begin{array}{l}N F F \\
\text { IBF }\end{array}$ & $\begin{array}{l}21.8 \\
26.8\end{array}$ & $\overline{23}$ & $\begin{array}{l}15.5 \\
18.9\end{array}$ & $\overline{2}$ & $\begin{array}{l}0.9 \\
0.7\end{array}$ & $\overline{2}$ \\
\hline \multicolumn{2}{|c|}{ Mean" } & $24.30 \mathrm{a}$ & - & $17.20 \mathrm{a}$ & - & $0.80 \mathrm{c}$ & - \\
\hline Coratina & $\begin{array}{l}N F F \\
\text { IBF }\end{array}$ & $\begin{array}{l}19.6 \\
24.4\end{array}$ & $\overline{24}$ & $\begin{array}{l}17.5 \\
19.7\end{array}$ & $\begin{array}{c}- \\
13\end{array}$ & $\begin{array}{l}1.0 \\
0.8\end{array}$ & $\overline{20}$ \\
\hline \multicolumn{2}{|c|}{ Mean" } & $22.00 b$ & - & 18.60a & - & $0.90 b$ & - \\
\hline Egazy & $\begin{array}{l}N F F \\
\text { IBF }\end{array}$ & $\begin{array}{l}15.8 \\
20.6\end{array}$ & $\begin{array}{c}- \\
30\end{array}$ & $\begin{array}{l}6.1 \\
7.7\end{array}$ & $\begin{array}{c}- \\
26\end{array}$ & $\begin{array}{l}1.2 \\
0.8\end{array}$ & $\begin{array}{c}- \\
33\end{array}$ \\
\hline \multicolumn{2}{|c|}{ Mean } & $18.20 \mathrm{c}$ & - & $6.90 \mathrm{~b}$ & - & $1.00 \mathrm{a}$ & - \\
\hline \multicolumn{2}{|c|}{ L.S.D. 0.05 between cultivars } & 1.9 & - & 2.3 & - & 0.10 & - \\
\hline Mean & $\begin{array}{c}\text { NFF } \\
\text { IBF }\end{array}$ & $\begin{array}{l}20.05 \mathrm{~b} \\
25.18 \mathrm{a}\end{array}$ & $0 . \overline{20}$ & $\begin{array}{l}14.18 \mathrm{~b} \\
16.75 \mathrm{a}\end{array}$ & $0 . \overline{15}$ & $\begin{array}{l}1.08 \mathrm{a} \\
0.78 \mathrm{~b}\end{array}$ & $0 . \overline{27}$ \\
\hline L.S.D. 0.05 b & tween treatments & 1.5 & & 2.1 & - & 0.1 & - \\
\hline
\end{tabular}

*Mean followed by the same letter (s) are not significantly different at 0.05 level . NFF $=$ Normal Farm Fertilization

$\mathrm{IBF}=$ Integrated Balanced Fertilization
Data of the correlation coefficients were used to predict the relations between leaf nutrients contents and olive yield. In this concern, the data showed positive relationships between olive yield and leaf-nutrients content. The highest value was occurred for potassium $(\mathrm{r}=0.63)$, however, the lowest value was for manganese $(\mathrm{r}=0.08)$. 
In terms of the relations between oil percentage and leaf-nutrients content, the data showed positive responses with potassium, copper, calcium and phosphorus in a descending order. In contrast, negative actions were obtained with nitrogen, magnesium and manganese .

Concerning total acidity percentage, the results indicated that there were widely negative relations with nutrients which ranged between $(r=-0.72)$ for potassium and $(r=-0.06)$ for Manganese.

The relationship between olive yield, oil percentage and total acidity percentage, the results showed a positive relation between olive yield and its oil content $(\mathrm{r}=0.20)$. On the other hand, negative relations were found between each of them and total acidity percentage $(\mathrm{r}=-0.48$ and -0.14 , respectively).

Table(3)showed that there were significant differences in yield, oil and total acidity of olive cultivars as affected by IBF program. The average values of the two seasons revealed that the increments of olive production of the four tested cultivars raised by 23-30\% comparing to the initial treatment. Meanwhile, in case of oil percentage the increasing rate was ranged from $13-26 \%$ over control. Otherwise, the total acidity was decreased by rate of $20-33 \%$ due to using integrated balanced fertilization program. On the other hand, the highest olive yield was $28.9 \mathrm{~kg} /$ tree associated with $20.7 \%$ of oil and $0.7 \%$ total acidity for the doublepurpose cultivar (Picual) and the lowest one was 20.6 $\mathrm{kg} /$ tree associated with $7.7 \%$ of oil and $0.8 \%$ of total acidity for the table-purpose cultivar (Egazy), under the IBF fertilization program.

\section{DISCUSSIONS}

The mean values of leaf nutrient contents of the four olive tested cultivars revealed that the IBF fertilization treatment produced an improvement results than found in control. The key role of integrated balanced fertilization (IBF)in increasing of leaf nutrients content was due to its favorable effects such as improving some soil chemical properties (Gallardo-Lara \& Dogales, 1987). Subsequently, apply an increments created nutrient balance in the root medium, which was a real reflection to their concentration in the leaf tissues.

The obtained finding are in line with the results reported by (Shaaban et al., 2004). On the other hand, the improvement of nutritive status of four olive cultivars in response to micronutrients application may be attributed to better balance between macro- and micronutrients. Such results were in agreement with that mentioned by (Mengel \& Krikby, 1987 and Rezk et al., 2005 ).

Hence, the applying of IBF program which combined of macro- and micronutrients in a balanced form is very important to achieve good nutritive status for olive trees.

Referring the response of olive cultivars to the fertilizer treatment, it is quite evident that there were significant differences among cultivars in the two studied seasons. In this respect, Zaherieva (1982) reported that the same plant species and varieties adapted better to unfavorable soil condition than others as well as there are wide difference among varieties in their nutrient requirements. While, Ahmed et al., (1998) mentioned that those differences mainly due to genetically factors.

The studied cultivars were positively affected and varied in their response to IBF program. However, the cultivars were widely differed in their leaf nutrient contents which reflecting on olive yield and its quality. In general, Manzanello showed the highest leaf nutrient contents among the tested cultivars and Picual gained the highest values of olive yield and oil percentage associated with lowest total acidity. This indicating the importance of the ratio between nutrients (balancing nutrition) rather than only leaf nutrient contents. On the other hand, the results of correlation coefficients indicated the promising role of nitrogen, potassium and copper for improving the yield, oil percentage and decreasing the acidity. This might be attributed to the improvement in plant physiological processes and reflecting on yield and its quality. Nofal et al., (1999) and Rezk et al.,(2005) indicated the same findings.

It can be concluded that using an integrated and balanced fertilization program (IBF) can be improve the physiological performance of olive cultivars which reflects on their yield and its quality.

\section{REFERENCES}

Ahmed, F.; A. E. M. Mansour and A. M. Ahmed (1998). A comparative study on fruiting of nine mango cultivars grown under new reclaimed sandy soils. Egypt. J. Hort. 25(2): 187-193.

Chapman, H. D. and P. F. Pratt (1978). Method of Analysis for soils, Plant and Water, Div. of Agric. Sci. Priced Pub. 4034 Univ. of California, U.S.A.

Fernandez-Escobar, R. (1998). Diagnostic del estado nutritivo y fertilizacion del olivar. Phytoma. 102: 54-55.

Gallardo-Lara, F. and R. Doglas (1987). Effect of the application of town refuse compost on the soil-plant system: A review. Bil. Wasts. 19:35. 
Hanson, E. (1996). Fertilizing fruit crops. Michigan state Univ. Ext. Bull. E - 852: 1-31.

Mengel, K. and E. A. Krikby (1987). Principles of Plant Nutrition, $4^{\text {th }}$ Ed. Pub. IPI (bern), 687.

Mobarak, Z. M.; A. A. El-Bendary and F. E. Abdalla (1992). Varietal difference in micronutrient uptake by Soybean grown on different soils. AJAS. 19 (1): 95-106.

Nofal, O. A.; M. F. El-Masri and F. E. Abdalla (1999). Effect of specific balanced fertilization on An apple yield. J. Agric. Sci., Mansoura Univ. 24 (9): 4989-4997.

Procpio, J. and A. Wallas(1979). Mineral elements concentration of leaves of 23 varieties of olive. Alex. J. Agric. Res. 27 (1): 51-54.

Reuter, D. J. and J. B. Robenson (1986). Plant Analysis (ed.). Inkata Press, Mellbourne, Sedney.pp: 217.
Rezk, A. I.; O. A. Nofal and M. F. El-Masri (2005). A comparative study on fruit quality parameters and yield of four olive cultivars grown in sandy soil. Arab Univ. J. Agric. Sci., Ain Shams Univ., Cairo. 13 (3): 891-899.

SAS Institute (1988). PC-SAS user's guide. Statistics SAS Inst., Cary. NC.

Shaaban, M. M.; O.A. Nofal and R. Kh. M. Khalifa (2004). Proper fertilization induced nutrient balance and increased yield of apricots grown under sandy soil conditions. Minufiya J. Agric. Res. 29 (4): 965 - 974.

Viesman, Z.; M. Luber; A. Ronen and A. Markus (2002). Ferti-vant-A new nondestructive and long-lasting in vivo system for foliar nutrients. Acta Hort., International Symposium on Foliar Nutrition of Perennial Fruit Plants.

Zaharieva, T. (1982). Effect of genotype and iron, applied soil on the chemical composition and yield of some plants. In Genetic Specialty of Mineral Nutrition of Plant. Saric M. A. (ed.), Vol. XIII, No. 3 P. 141, Serbia, Academy of Science and Art., Belgrade. 


\section{الملخص العربي}

\section{تحسين انتاجية وجودة محصول بعض أصناف الزيتون بإستخدام نظام التسميد}

\section{المتكامل والمتوازن فى الأراضى الجيرية}

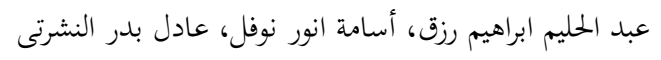

والحديد (ر = - 0.33).ولقد اتضح أن للبوتاسيوم والنحاس

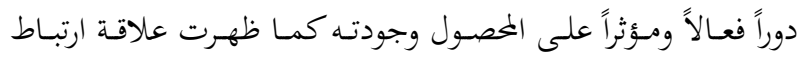

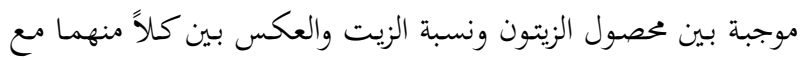

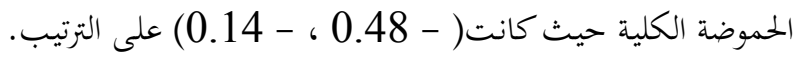
كذلك فإن مصول الزيتون للأصناف الأربعة و محتوى الزيت زاد كثيراً

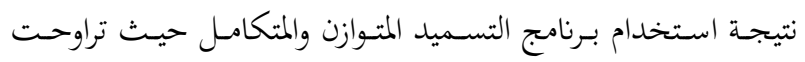

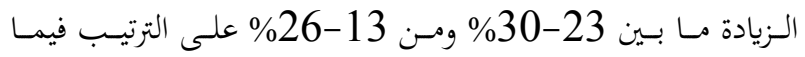

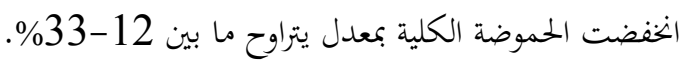
وطبقاً لذلك كان أعلى معصول زيتون 28.9 كجم/شجرة

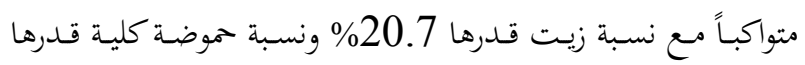

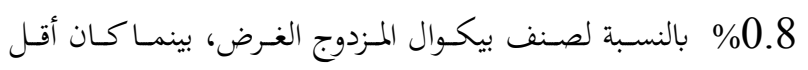

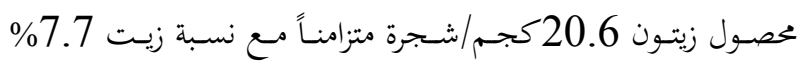

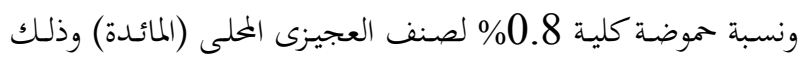
تحت نظام التسميد المتوازن والمتكامل(IBF).

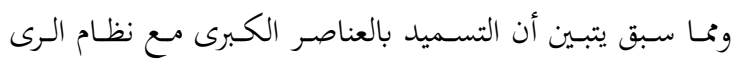

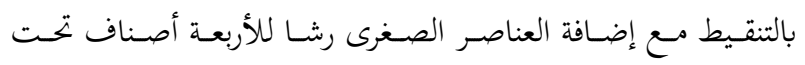
الدراسة كان له دورا هاما وفعالا بدرجات متفاوتة في تحسين محصول العاصن

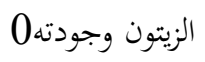

تم تقييم 4 أصناف زيتون عمر 10 سنوات ذات أغراض إنتاجية مختلفة (زيت - مائدة- مزدوجى الغرض) فن أراضى جيرية تحت نظام

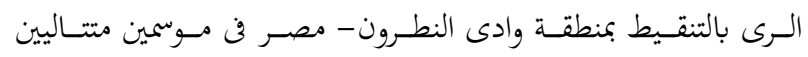
2006 ، 2007تحت نظـام التسـميد المتسوازن والمتكامـل (IBF)

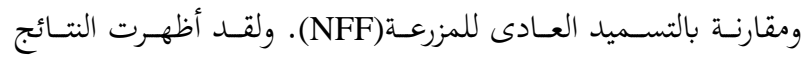

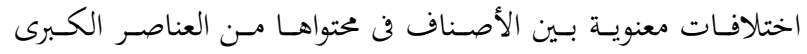

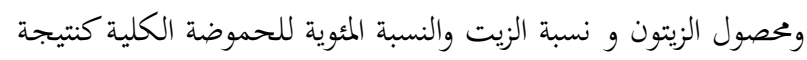

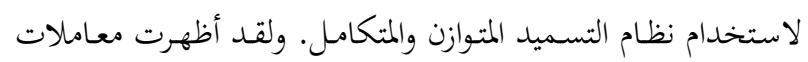
الارتباط بأن هناك علاقات إيجابية عالية بين الختوى الغذائى للورقة

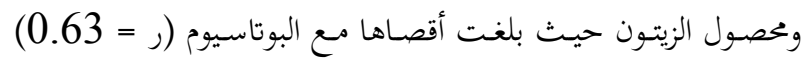
وكلا من النيتوجين والنحاس (ر = 0.58) وبالنسبة لنسب الزيت النيت النيان فإن العلاقات كانت إييابية وبخاصة مـع البوتاسيوم (ر =

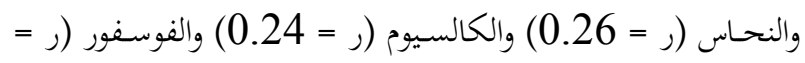

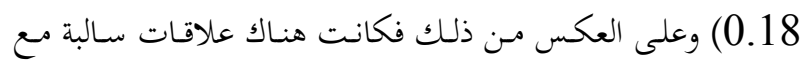

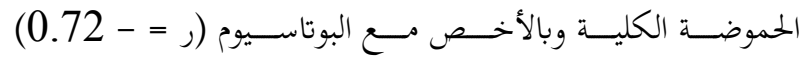

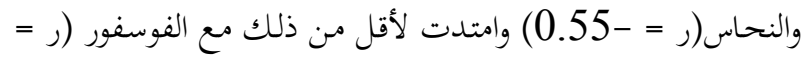

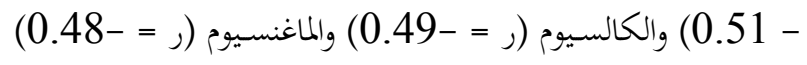
والنيتوجين ( ر= -0.58) ولكالميوم (0.38) 